\title{
EFFECT OF DIFFERENT STRUCTURE TYPE TRAFFIC ON RAILWAY LINE CAPACITY
}

\author{
Radosław Gleba \\ Sławomir Grulkowski \\ Jerzy Zariczny \\ Gdansk University of Technology, Poland
}

\begin{abstract}
The article points to methods of analyzing railway traffic conditions based on two parameters: capacity and delay of trains. The impact of the differentiated railway type structure on the capacity of the railway line was presented. Particular attention has been paid to the assessment of commonly used simplifications in analyzes.
\end{abstract}

Keywords: railway line capacity, railway traffic conditions, train delays

\section{INTRODUCTION}

Modernization activities at railway stations and railways bring tangible benefits in terms of improving the quality and competitiveness of the railways, which results in a significant increase in traffic on major rail lines. Investments in railway infrastructure should be of adequate durability (longevity) not only for the construction of railway pavements, earthworks or engineering facilities, but also to ensure adequate conditions for long-distance rail traffic. There are many methods for evaluating rail traffic conditions, the usefulness of which depends on the purpose, the input data, the appropriate computing tools, and the expectations of the accuracy of the mapping of reality. Analytical, optimization, simulation, and hybrid models, i.e. methods that combine both analytical and simulation elements, are distinguished. The simulation method, which takes into account the greatest number of variables and assumptions, is the simulation method done by the creation of computerized microsimulation model of the analyzed railway $[3,4]$.

Most often, however, due to the complex analysis process, the simplest analytical models are used, which often lead to incorrect conclusions at the pre-design stage. In practice, in many cases, this results in a mismatch of the railway line to the traffic flow required by the demand. This phenomenon is most noticeable in the large agglomerations, where demand for passenger transport is increasing in demand for freight. An example is the Tri-City agglomeration, where the growing demand for railways has a growing phenomenon of suburbanization and the increase in trans-shipments in the Tri-City seaports, which are one of the largest railway freight generators in Poland [2, 10, 14].

An additional factor that often misinterprets the results obtained with analytical models is the large variation in freight technology and the speed of freight trains $[7,8]$.

\section{PARAMETERS AND FACTORS DETERMINING RAIL TRAFFIC CONDITIONS}

One of the main characteristics of a railway line is its capacity, the largest number of trains or pairs of trains that can flow smoothly over a given line within a specified time unit (typically day or peak time) [18]. However, the capacity itself does not say much about the conditions and fluidity of rail traffic, as it is not a synthetic indicator. Railway lines with similar capacity values can in practice vary radically in terms 
of traffic flow. This is due to the large number of different factors affecting the capacity value. Comparative analysis of two railway lines or even two sections of the same railway line is possible only after comparing the capacity value with the current or predicted traffic volume. The synthesized indicator thus obtained is referred to as the capacity utilization rate and allows for an assessment of traffic conditions, including, among others, the infrastructure features of the reserve in case of traffic disruptions, the impact of different types of traffic $[9,16,20,21,23,24,29]$.

Capacity is defined primarily for routes, i.e. part of a railway line between two adjacent watch posts - stations or branch outlets. The value of the parameter is determined by the critical route or the critical section (in the case of routes equipped with self-locking line locks). This is a trail (stretch), which is characterized by the longest time of attachment of infrastructure by a passing train. A given time is referred to as the traverse time interval of trains and depends on:

- number and layout of tracks;

- arrangement and configuration of track circuits;

- the technical parameters of the line (in particular the permissible driving speed for each type of train);

- line geometry (values of horizontal radius and longitudinal radius);

- type of rail traffic control devices;

- $\quad$ type structure of movement (movement diversity);

- train speed spectrum (variation of permissible train speed);

- parameters of dynamic traction vehicles (traction characteristics);

- traffic organization (including train hierarchies and train initialization: eg "under green light” or “at green light”);

- driving techniques;

- location of passenger stops on the trails $[1,5,17,18,30]$.

\section{LINE CAPACITY}

The basic requirement for a complex analysis of traffic conditions on a railway line is to determine the capacity of individual routes. Under ideal conditions, where the structure of movement on the analyzed line segment is homogeneous, and trains run at the minimum tramline intervals, the line capacity is calculated according to $(1)[12,18]$. The given physical situation is shown in Figure 1.

$$
N_{\max }=\frac{T}{I_{n}}
$$

where:

$N_{\max }$ - maximum theoretical capacity [train/day or pair of trains/day];

$T$ - analyzed time window (essentially $24 \mathrm{~h}$ : $\mathrm{T}=1440 \mathrm{~min}$ ) [min];

$I_{n}$ - track time interval for trains $[\mathrm{min}]$

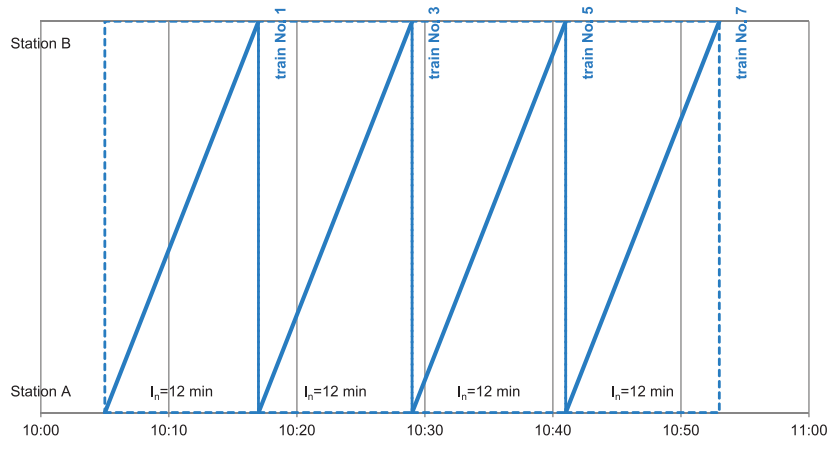

Fig. 1. Homogeneous movement of trains running at minimum intervals (source: own study)

The motion organization shown in Figure 1 provides the opportunity to launch the largest possible number of trains on the trail, but this is an idealized situation because, due to the lack of time between successive trains, it is highly susceptible to the possible formation and spread of primary traffic disruption, causing a high risk of secondary interference. In addition, most of the railway lines have a variation in the type structure of the trains running, so the load time of the route is variable. This situation is most likely to occur near large transport generators (e.g. harbor agglomerations). Variety of traffic influences the increase in speed range with which individual types of trains travel, and their movement is not evenly distributed in successive time intervals (so called windows). In fact, there are additional time reserves between successive trains to enable neutralization of possible interference (primary or secondary), thereby increasing system reliability $[22,23,26,27,28,31]$. Therefore, the value of the track successive time interval is individual for each train included in the timetable and consists of the time taken by the particular train and the preceding reserve of time (2). The heterogeneous structure of train traffic is shown in Figure 2.

$$
I_{n, i}=t_{o b, i}+t_{b, i}
$$

where:

$I_{n, i}$ - track time sequence corresponding to train and non-homogeneous motion [min];

$t_{o b, i} \quad$ - unit time of track occupancy [min];

$t_{b, i}-$ unit time reserve [min].

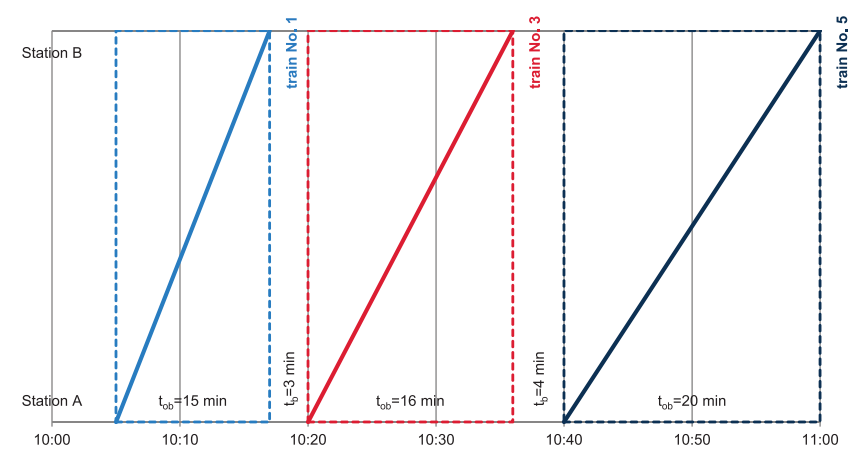

Fig. 2. Non-homogeneous structure of train traffic (source: own elaboration) 
The variety of train traffic combined with a large range of speed affects the difficulty in determining the capacity of the routes [18]. In the case of application of methods of analysis of railway traffic conditions in which some parameters describing railway transport system are standardized (e.g. parameters related to track geometry - arc rays, values of longitudinal gradients) and the relation between subsequent trains is not taken into account (skipping of the timetable), it is possible to calculate the theoretical capacity according to the relation (3).

$$
N_{t}=\frac{(1-\varphi) \cdot T}{t_{o b, \max }}
$$

where:

$N_{t}$ - Theoretical capacity [train/day or pair of trains/day];

$\phi$ - Fluidity coefficient of motion (for calculation is assumed $\varphi=0,2 \div 0,3)$;

$T$ - Analyzed time window (essentially 24h: $\mathrm{T}=1440$ $\min )[\min ]$;

$t_{o b, \max }$ - Maximum load time of the trail in the analyzed time window [min].

The approach assumes the possibility of the randomness of train reports, characterized by the greatest load on the trail. In the case, where trains with the highest infrastructure, take time in succession, the value of tob, max is actually the minimum train line interval. Where a track is being loaded by faster trains, the difference between the peak load time of the trail and the load of the trail over the faster train is treated as a time reserve. In addition, the so-called motion fluctuation factor $\phi$, which reduces the duration of the analyzed time window, provides a reserve for diagnostic and maintenance activities and possible neutralization of interference.

In many situations, calculations based on dependence (3) are unrepresentative. This particularly applies to routes where there is a significant difference in the minimum and maximum time of seizure of infrastructure. The method does not take into account the share of the different types of trains during the total time of the route during the 24-hour period, which can lead to the situation where one type of train, which has fixed time intervals, is a train that determines the capacity values for the whole analysis period (essentially 24 hours). Hence, using a given way of analyzing railway traffic conditions, it is important to be aware of the large number of simplifications that can affect the reliability of the research carried out.

These simplifications resulting from the application of dependence (3) can be depicted on the example of Kościerzyna - Gdynia railway section of line No 201 Nowa Wieś Wielka - Gdynia Port. Figure 3 shows the values of the maximum unit time of seizure of particular routes in selected time intervals. The value of this parameter is variable over time, and the difference between maximum and minimum can be significant. It is particularly noticeable in the case of an even track of Gdańsk Osowa (Os) - Gdynia Główna (GO) line section. The difference in the value of tob, max at night in relevance to the remaining time periods, is due to the fact that free freight trains ( 2 trains / d) are essentially launched in the given time interval. Due to the intensity and priority of passenger trains, there is no possibility of trains to travel at other time intervals. Therefore, for this case it is not appropriate to determine the capacity for the whole analysis period based on the value of tob, max determined by trains whose movement is not reliable for the whole section. In addition, the type of train is not representative of the section under consideration because of its low participation in the quantitative structure of trains - passenger trains: 48 trains/d; Freight trains: 2 trains / d [6].

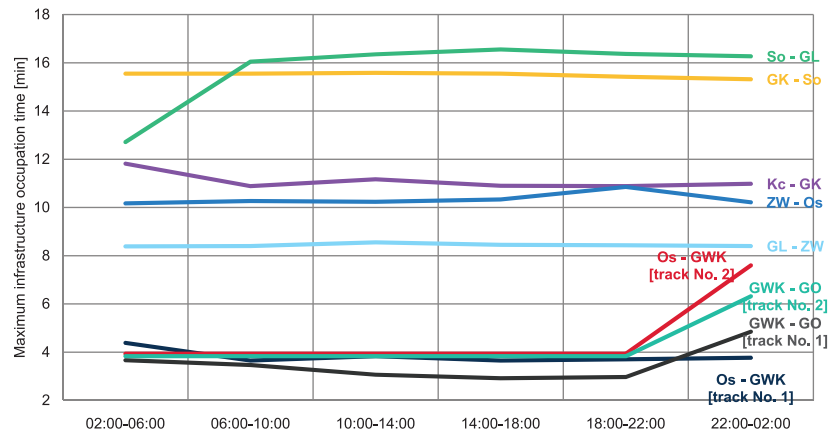

Fig. 3. The maximum busy time of individual pathways analyzed section of the railway line (markings: Kc - Kościerzyna, GK - Gołubie Kaszubskie, So Somonino, GL - Glincz, ZW - Żukowo Wschodnie, Os - Gdańsk Osowa, GWK - Gdynia Wielki Kack, GO - Gdynia Główna) (source: own elaboration)

As already mentioned, traffic on most railway lines is characterized by significant heterogeneity and high variability of train speeds, which translates into significant differences between minimum and maximum occupation times. This results in the need to take into account the appropriate simplifications, using the mean values $(4)[5,18]$. As a result, the calculation methodology presented below is representative of most railway lines in Poland (including the railway line 201 Nowa Wieś Wielka - Gdynia Port in the Kościerzyna - Gdynia section) as based on the average values taken into consideration is the structure of generic trains, their participation in the total time of route occupation during the day and time intervals.

$$
N_{p r}=\frac{(1-\varphi) \cdot T}{t_{o b, s r}+t_{b, o p t, s r}}
$$

where:

$N_{p r} \quad$ - Practical capacity [train/day or pair of trains/day];

$\phi$ - Coefficient of motion fluidity (for calculations it was assumed $\varphi=0,2)$;

$T$ - Analyzed time window (essentially $24 \mathrm{~h}: \mathrm{T}=1440 \mathrm{~min}$ ) [min];

$t_{o b, s r}$ - Average unit load time of the trail [min];

$t_{b, o p t, s r}$ - Acceptable average unit time interval between train reports [min]. 
The average unit load time of the trail in the analyzed time window is calculated as the quotient of the total time of the route load and the number of trains running:

$$
t_{o b, s r}=\frac{\sum_{i}^{n} t_{o b, i}}{n}
$$

where:

$t_{o b, s r}$ - Average unit load time of the trail [min];

$t_{o b, i}$ - Unit load time of the trail [min];

$n$ - Number of trains on the trail [-].

Determining the allowable average unit interval between subsequent train reports requires analyzing the time reserves in timelines. The first step is to isolate all of those intervals, which are smaller than tob,sr (6). It is assumed that these are intervals that cannot be used to trample subsequent trains, and therefore add to the average unit load time of the route, thus increasing the stability of the traffic graph and thus the reliability of the rail transport system on the analyzed section.

$$
t_{b, i}<t_{o b, s r}
$$

where:

$t_{b, i} \quad$ - Interval before the train i [min];

$t_{o b, s r} \quad$ - Average unit load time of the trail [min].

The values of time intervals satisfying the inequality (6) are then summed and divided by the number of trains on the path that meet the inequality (6). The value thus obtained is defined as the permissible average unit time interval between train reports:

$$
t_{b, o p t, s r}=\frac{\sum_{i}^{t_{b, i}<t_{o b, s r}} t_{b, i}}{\sum l_{i}}
$$

where:

$t_{b, o p t, s r}$ - Acceptable average unit time interval between train reports [min];

$t_{b, i}$ - Interval before the train i smaller than tob,sr [min];

$\Sigma l_{i}$ - The total number of trains on the trail that are characterized by value [-].

The calculation methodology is well illustrated in Figure 4, where the time reserve between the SKM96349 and SKM96351 trains cannot be used to tracer another train because it is less than the average unit time of the track. Consequently, the value of the interval time is taken into account when determining the acceptable average unit interval time between subsequent train reports and improves the stability of the timetable. The intervals between the SKM96341 and SKM96349 and SKM96351 and SKM96357 are higher than the average unit time of the trains, so they can be used to trample trains.

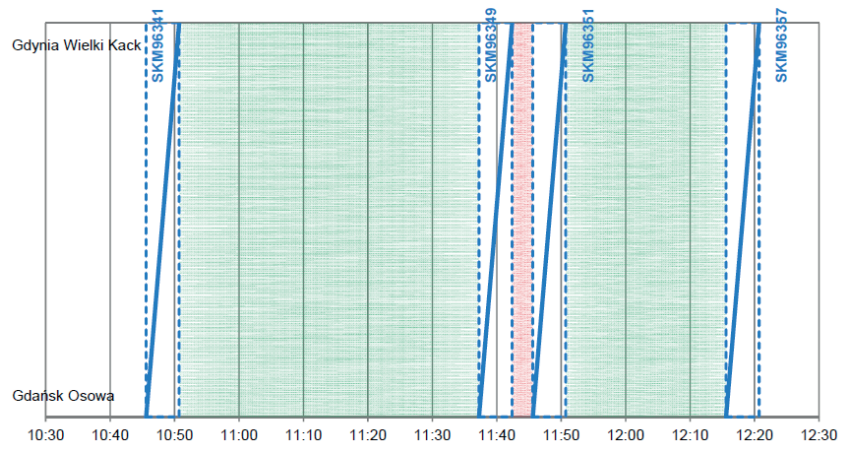

Fig. 4. Reserves of time between successive trains on track no. 1 of Os - GWK route

(source: own elaboration)

Practical throughput capacity based on the above presented methodology is the most representative basis for further analysis for lines characterized by high train speed variability and uneven traffic. Calculations based on the average load time of the trail allow to include the traffic structure in the calculation, because the greatest impact on the capacity value is the trains that have the greatest total infrastructure occupancy per day. The reliability of calculations is also enhanced by taking reserve of the time that affects the stability of the timetable. This is particularly important for punctuality of trains. In 2014, of all freight trains operating in Poland, as many as $58.6 \%$ were delayed, of which over $40 \%$ had delays of more than 16 minutes. In the same year punctuality of passenger trains was $91.1 \%$ [19].

\section{TRAIN DELAYS}

One of the most important indicators that best illustrates the reliability of rail operations is the spread of delays. Train delays can be divided into primary ones (caused by, for example, rolling stock or infrastructure failure) and secondary ones that have arisen as a result of primary delays. The risk of secondary delays is all the greater, the smaller the value of time intervals between subsequent trains. As a consequence, the greatest risk of secondary delays occurs when trains run at minimum track intervals (Figure 1). Determining the amount of secondary delays, depending on the value of the original delay of one of the trains in heterogeneous motion, requires a detailed analysis in which it is necessary to determine what kind of train follows its preceding, what is the time distance between them, and where observation is done on the line $[11,13]$. The issue is highly complex, which in practice uses simplifications, which, as in the case of capacity calculation, are based on average values. The basis for the analysis is the time reserve between train reports based on the average value:

$$
t_{b, s r}=\frac{\sum_{i}^{n} t_{b, i}}{n}
$$

where: 


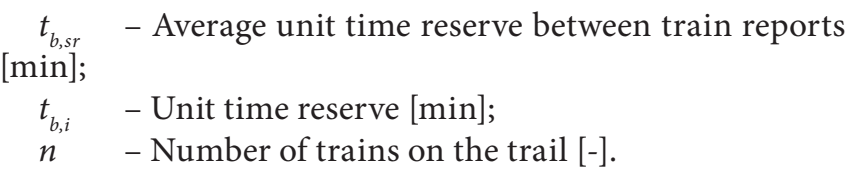

Determining the average unit value of the time reserve allows to specify the number of trains that will be subject to a secondary delay resulting from the original delay of one of the trains [13]:

$$
j=\frac{t_{d, 1, i}}{t_{b, s r}}
$$

where:

$$
\begin{aligned}
j & \text { - Number of trains covered by the secondary delay } \\
{[-] ; } & \text { - Value of original delay time of one of the trains } \\
t_{d, 1, i} & \text { [min]; } \\
t_{b, s r} & \text { - Average unit time interval between train reports } \\
\text { [min]. } &
\end{aligned}
$$

The next step is the sum of the delays [6]:

$$
\sum t_{d}=(j+1) \cdot t_{d, 1, i}-\frac{j}{2} \cdot(j+1) \cdot t_{b, s r}
$$

where:

$\Sigma t_{d} \quad$ - Sum of delays [min];

j $\quad-$ Number of trains covered by the secondary delay $[-]$

$t_{d, 1, i}$ - Value of original delay time of one of the trains [min];

$t_{b, s r} \quad$ - Average unit time interval between train reports [min].

The final result of the analysis is a graph showing the process of increasing the sum of delays depending on the original delay value of one of the trains (Figure 5).

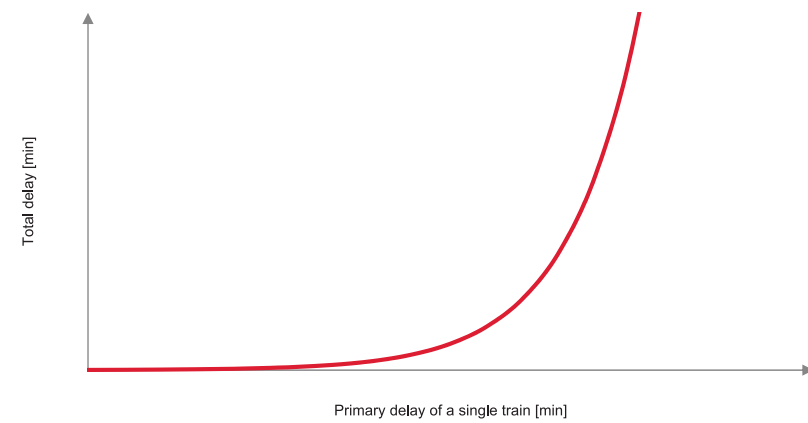

Fig. 5. The increase of the sum of delays depending on the original delay (source: own elaboration)

On the basis of the analysis, it was found that the calculations of the increase of delays made on the basis of the mean unit time interval between the reports of subsequent trains are characterized by considerable simplifications. This is due to significant unevenness in traffic and a large variation between actual reserves of time. Therefore, it is advisable to investigate the process of acceleration of delays only for specific traffic situations on a critical route, where it is possible to refer to actual rather than averaged time intervals.

\section{SUMMARY}

Two of the main parameters mentioned above: line capacity and trains delay are just a starting point for analysis with more parameters such as practical capacity, capacity utilization, timetable stability and organizational reliability. Only a comprehensive analytical approach, based on the individual characterization of each train, allows for a fair assessment of traffic conditions on lines of varying traffic pattern.

From the point of view of the management of the transport process, where intramodality is a major challenge and a contemporary duty, optimizing system reliability in terms of technological and technical aspects becomes absolutely desirable and above all else - possible [15, 19, 24, 25].

\section{BIBLIOGRAPHY}

1. Abril M., Barber F., Salido M.A., Tormos P., Lova A.: An assessment of railway capacity, Transportation Research Part E: Logistics and Transportation Review, Volume 44, Issue 5, September 2008.

2. Burdziakowski P., Janowski A., Kholodkov A., Matysik K., Matysik M., Przyborski M., Szulwic J., Tysiąc P., Wojtowicz A.: MARITIME LASER SCANNING AS THE SOURCE FOR SPATIAL DATA// Polish Maritime Research. -Vol. 22, Iss. 4(88) (2015), pp.9-14.

3. Dymarski C., Dymarski P.: Computational simulation of motion of a rescue module during its launching from ship at rough sea// Polish Maritime Research. -Vol. 21, nr. 3(83) (2014), s.54-60.

4. Dymarski P., Dymarski C.: A numerical model to simulate the motion of a lifesaving module during its launching from the ship's stern ramp// Polish Maritime Research. -Vol. 21, nr. 2(82) (2014), s.34-40.

5. Gašparík J., Zitrický V.: Aspects of railway capacity and occupation time estimation, Journal of Civil Engineering and Architecture, Volume 8, No. 3, March 2014.

6. Gleba R., Grulkowski S., Szczepiński D., Zariczny J.: Znaczenie analiz ruchowych w procesie optymalizowania zakresu infrastrukturalnych inwestycji kolejowych, Materiały Konferencyjne, Nowoczesne technologie i systemy zarządzania w transporcie szynowym. Część II: Transport szynowy, sterowanie ruchem kolejowym, SITK, Kraków 2016, s. 63-82. 
7. Gleba R., Grulkowski S., Zariczny J.: Problem zdolności przepustowej linii kolejowych w obszarze aglomeracji trójmiejskiej, Materiały Konferencyjne, Nowoczesne technologie i systemy zarządzania w transporcie szynowym, SITK, Kraków 2014, s. 145-166.

8. Gleba R., Grulkowski S., Zariczny J.: Wielowariantowa analiza wpływu modernizacji linii kolejowej nr 201 na dostępność kolejową gdyńskiego portu, Materiały Konferencyjne, Nowoczesne technologie i systemy zarządzania w transporcie szynowym. Część , SITK, Kraków 2014, s. 167-182.

9. Grzeczka A., Kłaczyński M., Wittbrodt E., Uhl T., Kohut P.: 2015. Motion analysis of a kitesurfer employing a visionbased measurement system// Journal of Vibroengineering. -Vol. 18, iss. 3 (2016), s.1884-1892

10. Janowski A., Nowak A., Przyborski M., Szulwic J.: Mobile indicators in GIS and GPS positioning accuracy in cities. 2nd International Conference on Rough Sets and Emerging Intelligent Systems Paradigms (RSEISP) held as part of Joint Rough Set Symposium (JRS), 2014, Springer International Publishing.

11. Królicka A.: State equations in the mathematical model of dynamic behaviour of multihull floating unit// Polish Maritime Research. -Vol. 17, nr. iss. 1 (2010), s.33-38.

12. Lai Y.C., Barkan C.P.L.: An enhanced parametric railway capacity evaluation tool (RCET), Proceedings of 88 th Transportation Research Board, Washington, DC, 2009.

13. Landex A.: Methods to estimate railway capacity and passenger delays - PhD thesis. Technical University of Denmark, Department of Transport, November 2008.

14. Lindfeldt A.: Railway capacity analysis - methods for simulation and evaluation of timetables, delays and infrastructure. Doctoral Thesis in Infrastructure. KTH Royal Institute of Technology, School of Architecture and the Built Environment, Department of Transport Science, Stockholm 2015.

15. Lipiński K., Docquier N., Samin J., Fisette P.: mechanical engineering education via projects in multibody dynamics// COMPUTER APPLICATIONS IN ENGINEERING EDUCATION. -Vol. 20, nr. iss. 3 (2012), s.529-539.

16. Mioduszewski P., : Inhomogeneity of low-noise wearing courses evaluated by tire/road noise measurements using the close-proximity method// APPLIED ACOUSTICS. -Vol. 111, (2016), s.58-66.

17. Mioduszewski P., Ejsmont J., Grabowski J., Karpiński D.: noise map validation by continuous noise monitoring// APPLIED ACOUSTICS. -Vol. 72, nr. iss. 8 (2011), s.582-589
18. Nowosielski L.: Organizacja przewozów kolejowych. KOW, Warszawa 1999.

19. Ocena funkcjonowania rynku transportu kolejowego i stanu bezpieczeństwa ruchu kolejowego w 2014 roku, Urząd Transportu Kolejowego, Warszawa 22 września 2015.

20. Sandberg U., Mioduszewski P.: The importance of the bottom layer in double-layer porous asphalt for noise reduction// Journal of the Acoustical Society of America. -Vol. 131, iss. 4 (2012), s.1-6.

21. Szłapczyński R., Szlapczynska J.: A Target Information Display for Visualising Collision Avoidance Manoeuvres in Various Visibility Conditions// JOURNAL OF NAVIGATION. -Vol. 68, iss. 06 (2015), s.1041-1055.

22. Szłapczyński R., Szłapczyńska J.: Customized crossover in evolutionary sets of safe ship trajectories// International Journal of Applied Mathematics and Computer Science. -Vol. 22, nr. No.4 (2012), s.999-1009.

23. Szłapczyński R., Szłapczyńska J.: On evolutionary computing in multi-ship trajectory planning, Applied Intelligence// APPLIED INTELLIGENCE. -, (2011), s.1-20.

24. Szłapczyński R.: Evolutionary approach to ship’s trajectory planning within Traffic Separation Schemes// Polish Maritime Research. -Vol. 19, nr. iss. 1(72) (2012), s.11-20.

25. Szłapczyński R.: Evolutionary Planning of Safe Ship Tracks in Restricted Visibility// JOURNAL OF NAVIGATION. -Vol. 68, iss. 01 (2015), s.39-51.

26. Szłapczyński R.: Evolutionary Sets of Safe Ship Trajectories Within Traffic Separation Schemes// JOURNAL OF NAVIGATION. -Vol. 66, nr. iss. 1 (2012), s.65-81.

27. Szłapczyński R.: Evolutionary sets of safe ship trajectories with speed reduction manoeuvres within traffic separation schemes// Polish Maritime Research. -Vol. 21, iss. 1 (2014), s.20-27.

28. Szłapczyński R.: Evolutionary Sets Of Safe Ship Trajectories: A New Approach To Collision Avoidance// JOURNAL OF NAVIGATION. -Vol. 64, nr. no. 1 (2011), s.169-181.

29. Szymkiewicz A.: Modelaling water flow in unsaturated porous media: Accounting for nonlinear permeability and material heterogeneity. Heidelberg: Springer, 2013.

30. Weryk M., Kozaczka E., Grelowska G.: Study of Noise Propagation for Small Vessels// Archives of Acoustics. -Vol. 40, nr. 2 (2015), s.267-272. 
31. Woch J.: Narzędzia analizy efektywności i optymalizacji sieci kolejowej. Wydawnictwo Politechniki Śląskiej, Gliwice 2001.

\section{CONTACT WITH THE AUTHOR}

Sławomir Grulkowski

e-mail: slawi@pg.gda.pl

Gdańsk University of Technology

11/12 Narutowicza St.

80 - 233 Gdańsk

Poland 